\title{
The Avant-Garde Sprachkritik of Paul Hatvani : Mysticism, Eroticism, and Heterodox Religious Experience
}

\section{Sjöberg, Sami}

\author{
2017-10
}

Sjöberg , S 2017 , ' The Avant-Garde Sprachkritik of Paul Hatvani : Mysticism, Eroticism, and Heterodox Religious Experience ', Journal of Austrian Studies, vol. 50 , no. 3-4, pp. 57-78 . https://doi.org/10.1353/oas.2017.0039

http://hdl.handle.net/10138/255651

https://doi.org/10.1353/oas.2017.0039

acceptedVersion

Downloaded from Helda, University of Helsinki institutional repository.

This is an electronic reprint of the original article.

This reprint may differ from the original in pagination and typographic detail.

Please cite the original version. 


\section{The Avant-Garde Sprachkritik of Paul Hatvani}

\section{Mysticism, Eroticism and Heterodox Religious Experience}

\section{Sami Sjöberg}

Die Nacht ist eine höher Dimension in der Reihe der Zeiten; ich glaube, Religion ist eine Wirkung der Nacht.

-Hatvani, Salto Mortale 69

The Wiener Moderne produced a variety of writers, artists, and philosophers, of whom Paul Hatvani (born Paul Hirsch, 1892-1975) was one of the lesser known. This Austrian-Jewish figure was a sort of Alleskönner in Viennese literary circles during the turmoil of the 1910s and 1920s. Even though he was simultaneously an author, journalist, and theorist as well as a literary and theater critic, Hatvani's oeuvre is fragmentary and eclectic. Stylistically, he favored brief pamphlet-like texts, typical of the germanophone avant-garde at the time, over lengthy, meticulous reflections. Hatvani was acclaimed by his peers and contemporaries, but after the Nazis' rise to power and his eventual emigration to Australia in 1939, his works went unnoticed apart from the few texts that are commonly included in anthologies on expressionism. Moreover, the fragmentary nature of his Nachlaß from the early 1910s and the interwar period has only added to the lack of attention his works have received over the decades, even though the historical avant-garde is currently undergoing a reevaluation from various theoretical viewpoints. A plausible reason for this oversight may well be the very scattered and unsystematic character of Hatvani's thinking: his texts are elliptic and associative. Moreover, his cosmology consists of varied elements, many of which are exclusive to the artist-poet, in a way that gives rise to a modern variant of mysticism. An overarching view of his theories reveals that regardless of his involvement in the avant-garde, he adopted elements from traditional Judaism as well as from Jewish mysticism - the Kabbalah—such as conceptions related to God.

The most noteworthy features in Hatvani's thinking are his ideas concerning the relation between language and religion, which are radically unconventional and are expressed through a language-critical attitude. Hatvani transgressed not only the language philosophy of his time but also dogmatic religion. This article focuses on Hatvani's particular version of Sprachkritik and addresses its relation to Jewish culture and mysticism in general as well as to gender dimorphism in kabbalistic theosophy in particular. ${ }^{1}$ In what follows, I will examine Hatvani's literary and 
Author's Accepted M anuscript. When citing this article, please refer to 'The Avant-Garde Sprachkritik of Paul Hatvani: M ysticism, Eroticism, and Heterodox Religious Experience', Journal of Austrian Studies, 50:3-4 (2017), pp. 57-78.

theoretical output by focusing on both his published works and unpublished material from his estate. ${ }^{2}$ The unpublished and so far largely unexamined documents broaden the current scholarly understanding of Hatvani's thinking, its significance to the avant-garde, and his contemporary Jewish context.

\section{A Viennese Jewish Intellectual}

Hatvani was the pen name of Paul Hirsch, who was born to a Viennese Jewish family in 1892. Between 1904 and 1911 the family resided in Budapest, where Hatvani grew up bilingual, speaking German and Hungarian. His first contact with the avant-garde, namely expressionism, took place there. He also contributed to various Hungarian literary journals, such as Haladás and Ma. After his return to Vienna in 1912 he studied mathematics and chemistry alongside his literary exploits. There he established contact with some of the leading figures of the germanophone avant-garde, such as Karl Kraus (who became a lifelong friend), Herwarth Walden, Franz Pfemfert, Salomo Friedlaender, Albert Ehrenstein, Berthold Viertel, Siegfried Jacobsohn, and Hermann Broch (Haefs 453). ${ }^{3}$ These figures were all of Jewish origin, but their relation to Judaism in general and the importance of Jewish issues in their thinking varied greatly. Hatvani nevertheless regarded his Jewish origins as a significant factor, at least in the sense of particularity, as his writings of the late 1910s reveal.

Hatvani embarked on a literary career early and with apparent success. In 1912 he sent three poems to Walden, who published them in the leading avant-garde magazine Der Sturm. That year some additional poems were published in the more conservative Der Brenner, and the 1913 anthology on Austrian expressionism, Die Pforte, featured eight more poems. His debut volume, Salto Mortale: Aphorismen, Essais, Skizzen (1913), presented all of these poems and additional writings, including essays such as "Der Fall Mensch," "Spracherotik," and the brief prose piece "Homunkulus." These texts undermined and ridiculed rationalism with unstinting devotion, and a new version of Sprachkritik was introduced in Austrian letters.

In the early 1900s numerous variants of Sprachkritik blossomed in Viennese intellectual circles. Sprachkritik originally emerged from a language crisis in Austrian letters at the turn of the century. ${ }^{4}$ Nineteenth-century rationalism, especially in the forms of positivism in philosophy and realism in literature, seemed to overlook the seminal role that language plays both in thinking and in man's relation to the world. Hatvani articulated the anti-rationalist stance of Viennese thinkers when he stated that "Überall betrügt uns die reine Vernunft. Die Vernunft ist ein Denkfehler des Menschens" (Salto Mortale 9). Accordingly, Sprachkritik focused on the epistemological dilemmas raised by trust in the opacity of language. It also presented a form of indirect social criticism for many writers, much in the vein of the French poètes maudits who in the 1880s rebelled against the (bourgeois) values and social order present in and mediated by language.

Preceding Hatvani, two major Austro-Hungarian thinkers had proceeded along similar 
Author's Accepted M anuscript. When citing this article, please refer to 'The Avant-Garde Sprachkritik of Paul Hatvani: M ysticism, Eroticism, and Heterodox Religious Experience', Journal of Austrian Studies, 50:3-4 (2017), pp. 57-78.

lines, namely Karl Kraus and Fritz Mauthner. Not unlike Mauthner in Beiträge zu einer Kritik der Sprache (three volumes, 1901-1903), Hatvani's philosophy of language asserted in various ways, occasionally with tongue in cheek, that man had no access to the world as such because man conceives the world via language and concepts, whereas "Die Welt ist ohne Sprache" (Landauer 224). ${ }^{5}$ Hatvani also echoes Kraus's famous thesis that "Wer nicht der Sprache vergibt, vergibt nichts der Sache" (Über die Sprache 7). ${ }^{6}$ Language obviously distorts any "direct" relation between a thing and its observer, the so-called subject-object scheme, but there seems to be no alternative to it.

Fundamentally, Sprachkritik posited an incongruity between the individual and universal reality, an incongruity caused and maintained by language. Mauthner, Kraus, and Hatvani illustrated this mismatch by adopting nominalism, which stated that even though general or abstract terms exist, universals or abstract objects - which were sometimes thought to correspond to these terms - do not. ${ }^{7}$ Nominalism addressed the epistemological level of language, on which Mauthner and Kraus focused. Hatvani, for one, regarded the rupture between the individual and the world in profoundly ontological terms, which may have spurred his interest in mysticism; or mysticism may have affected his approach to the aforementioned rupture. He became familiar with the idea of existence monism, which asserted that everything that exists is one single concrete thing (see Goff 40-45). Appropriately, both monism and extreme nominalism maintain that there exists only one individual, so all is one. In this context, nominalism deals with the linguistic realm, while monism is related to the ontological "beyond language." However, in Hatvani's case, these categories are constantly under negotiation due to the influence of the avant-garde and the promotion of the particularity of poetic language. Expressionism sought to fuse the individual and reality together into a kind of idealized "primeval monism," which reiterated similar claims abundant in mysticism (e.g., Bojtár 369). In ontological terms, this signified the "oneness" of experience and expression, thus intentionally blurring the line between epistemological and ontological inquiry.

In addition to the theories of Mauthner and Kraus, Salto Mortale seems to be inspired by Carl Einstein's Bebuquin, published in full a year earlier, in its critique of rationalism and naive realism. However, the form of Sprachkritik which Hatvani introduced in his early book-but never systematized - is distinct in its rather unique amalgam of eroticism, religion, and language. He associated erotic desire with religious desire, and the place where this desire is actualized is language - not just any language but the poet's language in particular. Preceding the Wiener Moderne, similar gendered and eroticized conceptions were abundant in the cosmologies of the various schools of Jewish mysticism, such as the Zoharian and Lurianic Kabbalah. ${ }^{8}$ Such notions had engendered a relation between eroticism and religious experience already in the Middle Ages in a manner distinct from traditional Judaism (see Wolfson, "Occultation of the Feminine" 37). Therefore, within this framework, religion must be understood in a particular antinomian and heterodox sense. In Hatvani's case, heterodox means that while religion maintained many of its formal elements, the content he assigned to concepts such as God or "the Element" (the 
Author's Accepted M anuscript. When citing this article, please refer to 'The Avant-Garde Sprachkritik of Paul Hatvani: M ysticism, Eroticism, and Heterodox Religious Experience', Journal of Austrian Studies, 50:3-4 (2017), pp. 57-78.

Godhead) was radical in a modern context.

As well as the Jewish mystical tradition, the eroticized Sprachkritik of Hatvani mirrors the Wiener Moderne in its apparent indebtedness to Nietzsche, who was one of the major philosophers influencing early expressionism in the German-speaking world. Hatvani did not repeat Nietzsche's ideas verbatim but regarded Nietzschean divine thanatology as enabling an alternatively conceived divinity. Hatvani's personal idea of God was not the one propagated by traditional religions but rather one conceived through language — even though he opted to designate God's name as ineffable, thus providing an obvious link with Jewish mysticism. Another aspect, also due to Nietzsche's influence, is more controversial from a current perspective. In expressionist circles Nietzsche's idea of the Übermensch often entailed a male chauvinist aspect. The Übermensch was interpreted almost exclusively as a man with various superior intellectual properties. The feminine, in turn, was associated with bodily matters and especially with sexual availability (see Wallach). In one of Hatvani's most renowned texts, "Spracherotik," the feminine acquires a metaphorical and instrumental value, but the same biased aspect is nevertheless manifested. ${ }^{9}$ In order to understand Hatvani's hypostatized ideas of language and poetic experience, one must, however, read the overall conceptualization of the feminine with a grain of salt, as is appropriate in its proper language-critical context.

The eroticism in "Spracherotik" is described through a dynamically transforming androgynous figure, which establishes at the very least a structural affinity with the kabbalistic ideas concerning anthropomorphism. ${ }^{10}$ A recent feminist reading of the Kabbalah allows the underlying affinities between kabbalistic and Hatvani's cosmologies to surface. Indeed, what can be called gendered mysticism entails a particular link between the artist and the feminine, which revises kabbalistic theosophy within an aesthetic framework. Ideally, the link would allow unification of the "male and female aspects" of language and experience. As noted above, Hatvani applied both nominalism and monism in a heterodox way. Arguably, his distinct version of Sprachkritik culminated in a heterodox sense of religion, which should nevertheless be understood against the backdrop of Judaism.

Fittingly, Hatvani did not opt for a conventional, tradition-derived definition of Judaism, nor of Jewishness for that matter. His essay "Jüdische Besinnung" (1917) exemplifies his rather unique manner of grasping these terms:

[E]ine Bewegung ist lebensfähig, wenn sie schöpferisch ist; wenn das Wort, das sie verkündet, Tat ist und Tat wird. Die neue jüdische Besinnung ist nicht nur religiös; aber sie schließt das Religiöse in sich ein und geht darüber hinaus. Deshalb ist ihr auch jede Form und jede Art von Religiosität wertvoll; sie hat die chassidische Bewegung in sich aufgenommen und wird auch der Kabbala noch gedenken müssen und aller jener krausen Offenbarungen jüdischen Geistes, die man wohl "die Gotik des Judentums" nenne darf. [. . .] "Denken" ist eine Abstraktion der Tat ins Metaphysische hin; die jüdische Besinnung unsrer Tage ist im Gedanken erschaffen und wirkt als Geist in unsrer Zeit. (719)

Appropriately, for Hatvani, "Gotik" signified "eine Revolte gegen den Inhalt" (Hatvani, "Der 
Author's Accepted M anuscript. When citing this article, please refer to 'The Avant-Garde Sprachkritik of Paul Hatvani: M ysticism, Eroticism, and Heterodox Religious Experience', Journal of Austrian Studies, 50:3-4 (2017), pp. 57-78.

Expressionismus ist tot ..." 4). He therein linked the future of Judaism with rebellion against the traditional content of that religion. At the same time, he promoted the unity of the Jews through a panoptic view of Judaism, regardless of the diverged field of religious beliefs and trends-he was, obviously, well acquainted with both the history of Judaism and its contemporary variants. ${ }^{11}$ Moreover, Hatvani identified a common denominator in the varied schools of thought: the verbal aspect of Creation. ${ }^{12}$ The all-encompassing community he proposed would include the Hasidim, the neo-kabbalists (e.g., Oskar Goldberg of Der Neue Club), both the orthodox and liberal Gemeinde, and various expressionist adaptations of the Jewish faith. In addition, Hatvani's own heterodox thinking regarding religion would be associated with Judaism. His view was that Judaism should evolve dynamically following the beliefs of people who perceived themselves as Jews instead of adhering to a preordained dogma. This was a radical revision of the traditional understanding of Judaism where both orthodox and reformist movements follow the basic tenets of the religion, such as rituals and sacred literature (the Torah and Tanakh). Yet, Hatvani concluded that such traditions could be done away with because Jewish self-identification was an abstract matter not limited to ethnic considerations.

Without the grounding provided by religion, self-identification thus became a somewhat fortuitous matter. Therefore, Hatvani took up abstraction as a mode of thought and not only the means of expression it would become in "mainstream" expressionism. Such a mode of thinking corresponds to his language philosophy, which sought to erase language of ideologically charged meanings (Judaism, for instance) and highlight poetic language in order to illustrate the rupture with "universal" reality.

\section{Hatvani's Eroticized Sprachkritik}

Hatvani composed his Sprachkritik in relation to current developments in the avant-garde, focusing on the author's subjective experiences and Weltanschauung. According to him, conventionalists tend to "kleben am Wort und das Wort muß sich den Parasitismus falscher Deutung gefallen lassen" ("Der Expressionismus ist tot . . ." 4). This stubborn fixation on words and meanings was rendered absurd by Hatvani's Sprachkritik. In his undated manuscript "Bemerkungen zum Zeitalter und Stil des Expressionismus in der Deutschen Literatur," Hatvani formulated the idea that "ein wesentlicher Aktionsinhalt der neuen Richtung [Expressionismus] sei, entscheidend jede vorher bestandene Sprachform zu negieren" (19). Such a strict criticism of language was necessary because language itself was seen as advocating the prevailing modes of thinking ("Fehlrationalisierung der Weltgeschichte" 2). As Foucauldian criticism would later make commonly known, language promoted dominant value systems and conventional modes of thinking, such as rationalism. Therefore it should be either eradicated or renewed. Accordingly, Hatvani's radical approach to language foregrounded alternative uses and unconventional forms of language, poetry being a cardinal instance.

The most seminal text in this context is "Spracherotik," which undermines the utilitarian 
Author's Accepted M anuscript. When citing this article, please refer to 'The Avant-Garde Sprachkritik of Paul Hatvani: M ysticism, Eroticism, and Heterodox Religious Experience', Journal of Austrian Studies, 50:3-4 (2017), pp. 57-78.

way science utilizes language without delving into the very basic problematics of the medium itself, namely the mediation of meanings. Hatvani notes how such epistemological problems could not be overlooked:

Die Wissenschaft macht sich über Endlichkeit und Unendlichkeit schon deshalb keine Gedanken, weil sie behauptet, daß die Gedanken die Wissenschaft machen. Aber die Sprache kommt zu kurz. Wohl glaubt man zu wissen, daß es Worte gibt und man sich bei jedem Wort etwas denken müsse ... aber man ist jedesmal sehr entrüstet, wenn man erfahren hat, daß das Wort auf die Gedanken seiner Erzeugers verzichtend, sich sein Teil selber denkt. Und zwischen Endlichkeit und Unendlichkeit hat das Wort Raum genug, um auf die Mithilfe der Gedanken verzichten zu können. Aber in der Gedankenlosigkeit der "wissenschaftlich"—d. h. mechanistisch—gebildeten Hirne ist kein Platz zum Spracherlebnis. Die Sprache ist eine Grenzenlosigkeit, die sich durch Gedanken nicht beschränken läßt. Das Wort ist eine Grenze und von Wort zu Wort ist ein weiter Weg. Die Wortbeziehungen, die man Grammatik nennt, dünken mir wie kaum erahnte Symbole einer transzendenten Sprachlogik—oder der Logik überhaupt—; eine neue Dimension der Geschehnisse baut sich auf, die Welt ist sprachlos, denn sie kann den Raum nicht finden, wo sich die Sprache selbst erlebt. Die uralte Tatsache des Spracherlebens muß erst neu entdeckt werden, zu einer Zeit, wo auch neben der Bildnismalerei eine neue Kunst der Farben und Formen zu entstehen scheint. ("Spracherotik" 210)

As yet Hatvani iterates the basic premises of Mauthner's Sprachkritik, namely the overall nominalist conception of language's character. ${ }^{13}$ For Hatvani, language was not only devoid of any "natural" relation to reality, it could not be subject to the intentions of its users. Hence, language was autonomic: it would not reliably repeat the thoughts of its user, and scientists were oblivious to this fact. For the Sprachkritiker, the irony is that science aspires to describe reality by the very means that render the whole endeavor impossible. Hatvani's critical attitude toward the prevailing modes of thought was emphasized by his idea of Spracherlebnis. In a nutshell, Spracherlebnis is an experience about language and its sovereignty. Such an experience highlights the absence of both the origin of language and the human interlocutor: to apply a touch of Heidegger-ese in conjunction with the above quote, "die Sprache spricht" precisely because "die Welt ist sprachlos."

More importantly, Hatvani drew a crucial parallel with mysticism by stating that the "age-old fact" of language experience must be rediscovered. It opens a link to mysticism where the character of language was grasped as fundamentally different from its modern usage. Päivi Mehtonen has perceptively recounted Sprachkritik's inclination to mysticism and its contribution to the avant-garde by highlighting that "medieval mysticism did not merely provide pre-war intellectuals and culture bohemians with an ideal mystical-social rebellion but also [. . .] a critical philosophy of language that explores the linguistic identities and suspensions" (142). For many an avant-gardist, such a skeptical mysticism contained readily available means for questioning language, which is to say that mysticism preceded Sprachkritik in its critical approach to language. I will return to mysticism later on, but it is important to outline here the link between 
Author's Accepted M anuscript. When citing this article, please refer to 'The Avant-Garde Sprachkritik of Paul Hatvani: M ysticism, Eroticism, and Heterodox Religious Experience', Journal of Austrian Studies, 50:3-4 (2017), pp. 57-78.

Spracherlebnis and the vanguard artist. Hatvani suggests that any true Spracherlebnis requires an artist, a writer, who realizes the sovereign character of language. The poet is able to compose poetry by virtue of realizing the very non-relation between language and reality. For Hatvani, Sprachkunst thus signifies the construction of aesthetic works that relate to reality contingently, that is, only by means of association or metaphor. ${ }^{14}$ In other words, language has to be experienced "as such," and this experience is the prime requisite enabling aesthetic creation.

Surprisingly, here lies the affinity linking Hatvani's Sprachkunst, the Torah, and original Creation. Similar imitatio Dei to Hatvani's was by no means a rare conception among the avantgarde poets of the early twentieth century, but for him Sprachkunst recalled the actual language of Creation. In this sense Hatvani came close to medieval mystics. He emphasized the sense of divine language being the prime mover of Creation: that language exercised its creative ability while transmuting words into matter. In a like manner, Hatvani relinquished the conception of words and things as diametrically opposed, theorizing instead a dynamic interchangeability between the formal and contentual aspects of an esthetic work.

This dualistic interchange evokes a noteworthy aspect of Hatvani's poetics due to its erotic emphasis. The dynamic flow between the dualistic poles gained an erotic aspect as Hatvani assigned masculine and feminine denominators to the different aspects of his language theory:

Den schaffenden Künstler bindet ein sexuelles Verhältnis zu seiner Materie und daher zur Welt überhaupt; denn die Materie seiner Kunst ist für ihn ein symbolisches Abbild der Welt. Der Sprachkünstler muß die Sprache vorerst zertrümmern, den chaotischen Urzurstand, eine absolute Homogenität der Materie herstellen, damit das Formlose, das Weib daraus werde. Dann beginnt sein Werk. "Im Anfange schuf Gott den Himmel und die Erde . . . Und Gott sprach . . ." Die Gegensätze teilen sich, das Formlose bekommt Inhalt und das Inhaltlose Form,- und siehe, das Weib wird schwanger bei der Berührung des Mannes. Klang und Kasus werden logisch wie alle Alliterationen und der Genitivus ist wie ein herrischer Ruf nach dem Besitz des Weibes. Die Bedeutungen streiten um das Vorrecht des besten Platzes und Alles will symphonisch in die Welt dringen, liebend und siegend, eine Welt für sich. "So sehr siegt die bloße Stellung, sei es der Krieger, sei es der Sätze." Der geniale Künstler—genial ist keine Relation, sondern eine organische Eigenschaft—wird schöpferisch an seiner Welt, die er als Weib fühlt; das Material seiner Kunst aber muß ihm die Welt ersetzen. Der Schriftsteller muß in der Sprache das Weib entdecken können und alle Phantasie, die er zur Zeugung seiner Werke nötig hat, muß eine Induktion der Sprache sein. ("Spracherotik" 210)

Hatvani outlined the idea that an artist establishes an unmediated relation with the world, thus enabling contact with that world beyond the sprachkritische level of language-by virtue of poetic language. Only after conventional language is eradicated can the possibility of art arise. It is noteworthy that for Hatvani the creative work of the artist was always characteristically masculine and thus opposite to the feminine. A similar arrangement was typical of the Kabbalah where "masculine" described the principle of giving and "feminine" receiving (Tirosh- 
Author's Accepted M anuscript. When citing this article, please refer to 'The Avant-Garde Sprachkritik of Paul Hatvani: M ysticism, Eroticism, and Heterodox Religious Experience', Journal of Austrian Studies, 50:3-4 (2017), pp. 57-78.

Samuelson 191). Appropriately, the artist was inclined to experience the world as feminine and thereby embrace its otherness. The Sprachkünstler was in an auspicious position because the feminine otherness could only be attained in and through language. This was not the conventional language of the scientist but rather of the poet.

By the same token, Hatvani suggested a new kind of epistemological relation altogether. The intimate character of the encounter between the masculine and feminine poles becomes disclosed by Hatvani's erotic imagery. However, here eroticism serves a language-critical function, namely in its ability to outline an unmediated relation between the experiencing subject (artist) and the experienced (feminine) that cannot be rendered into an object in any cognitive sense. Hence, the feminine can be experienced in its otherness-yet without being recuperated into the same, the masculine monad - and must be designated as "feminine" so that the dynamic relation between the artist and materia is enabled. The relation is "bodily," experiential, instead of linguistic.

Appropriately, Hatvani regarded the artist as a transceiver of emanations from the feminine. According to him, the world is nothing an sich but requires feminine otherness to "radiate" around the author: "Wie ist die Welt entstanden? Befruchtet und befruchtend, vernichtet und vernichtend, ein abgründiges Nichts: so sendet das Weib seine Strahlen um die einsame Monade 'Mann'" (Salto Mortale 17). Here Hatvani's somewhat satirical attitude to existence monism and dialectics is revealed. He posits the monadic man as a closed, monadic whole who is nonetheless only able to attain the world as an abysmal nothing-which is logical, should the monadic man be the sole existing thing. However, this constellation is immediately undermined by the existence of the dialectical feminine other. The erotic is evoked, because the feminine is beyond rational consciousness and its attempts to assimilate it. Hatvani clarified that "Nicht das Wissen ist das Wesen des Weibes, sondern das Sein. 'Weib sein' ist die ökonomischste Form von 'Mensch sein'" (Salto Mortale 18). Being, in the sense outlined here, cannot be grasped by means of rational consciousness. Hence, the feminine otherness is maintained by its hypostatized aspects, which remain beyond the male grasp.

The motivation for Hatvani's gendered aspects of experience may indeed derive from kabbalistic theosophy. Elliot R. Wolfson has convincingly shown that the visions of the (kabbalist) mystic are phallic in character. The word phallic here does not denote any physical organ but rather connotes an imaginary symbol. As such, the phallus is absent until one becomes aware of it through castration - that is, via its negation. So the so-called veiled phallus is both analogical to the structure of visionary experience and "the ultimate object of contemplative vision in the kabbalistic literature" ("Imagining the Imageless" 59). Even though Hatvani did not apply the term phallus, the rhetoric of an erotic encounter is omnipresent in a designation like "Spracherotik." The mutual otherness of the masculine and the feminine can also be expressed in terms of presence and absence, which are appropriate in the context of the Kabbalah. In these ontological terms, that "which is disclosed is concealed, indeed the very act of disclosure is a form of concealment; alternatively expressed, what is most visible is the invisible" (59).<?> 
Author's Accepted M anuscript. When citing this article, please refer to 'The Avant-Garde Sprachkritik of Paul Hatvani: M ysticism, Eroticism, and Heterodox Religious Experience', Journal of Austrian Studies, 50:3-4 (2017), pp. 57-78.

Likewise, the mystic craves contact with what is absent (God) and, hence, the unfulfillable desire is both religious and erotic in character. In the case of the artist, the craving is directed to the feminine other, but the underlying character of the desire is identical.

Hatvani further envisioned the feminine not merely as exemplifying a fundamental mode of being but also as an intermediary agent between the divine and the artist. In this way a contact with divinity necessitated an encounter with the feminine. The true pouvoir of the feminine became apparent in a sprachkritische context, as the feminine agent was able to replace conventional language:

Wohl ist die Sprache Ausdrucksform; aber eben das eignet sie dazu, ein Spiegel zu sein für die Eitelkeit des Weibes "Welt" und deshalb gibt es eine Sprachkunst. Kunst aber ist das erotische Verhältnis eines Mannes,_oder des "Männlichen"—, zu einer Materie die die Eigenschaften des Weiblichen hat: sie ist zwar homogen, ein Ganzes, besitzt aber die Fähigkeit, alle Gestalt anzunehmen, ein Mimicry des Lebens, - ein Weltembryo, das seines Schöpfers harrt. [. . . ] Das aber ist der Sinn der Welt: sie ist das Weib Gottes und seine Liebe ist unser Leben. ("Spracherotik" 210)

Echoing monism yet again, Hatvani postulates the feminine as a monad, but one with capabilities of transmutation. It cannot merely assume any shape whatsoever but rather every shape at once. Hence its idealistic monadic character would contain all variants of itself. However, the artist still remains distinct, so the monadic cosmology seems to be utterly undermined. Hatvani further postulated the feminine as a way to come into contact with the world created by God through poetic language. Here lies the essence of his Sprachkritik, which envisions a poetic and experiential alternative to conventional language. The contact with the feminine other in poetic language results in contact with the world of God, the one emerging from the verbal creation of the world. After Creation, art is the only means to come into contact with this world: "Kunst ist ein Umweg: ein Mann will zum Weibe und muß an der Welt vorbei" (Salto Mortale 71). This characterization echoes the idea of primeval monism promoted by expressionism. However, instead of suggesting a unification of the gendered aspects, it entails their suspended interrelation, culminating in the desire to reach the feminine.

\section{From Spracherlebnis to a Religious Experience}

The limits of language foregrounded by Sprachkritik suggest that Hatvani's quest to reach the feminine was imbued with abstraction. As noted above, for Hatvani, abstraction represented a particular "novel" mode of thought, one that would allow an unmediated relation with the world. Indeed, he formulated that thinking itself was a form of abstraction ("Versuch über Expressionismus" 719). ${ }^{15}$ This new consciousness would not support conventional modes of thought but rather required a new "para-cognitive" approach to the world. In Hatvani's universe, the artist became the harbinger of this novel modus operandi. Accordingly, "Die Lyrik ist eine 
Author's Accepted M anuscript. When citing this article, please refer to 'The Avant-Garde Sprachkritik of Paul Hatvani: M ysticism, Eroticism, and Heterodox Religious Experience', Journal of Austrian Studies, 50:3-4 (2017), pp. 57-78.

Ausdrucksform der [. . . ] Abstraktion" (Salto Mortale 10). In this case, abstraction bore no resemblance to the commonly perceivable reality in the fields of ontological or epistemological inquiry.

Furthermore, abstraction would provide a means of expression unconstrained by the overtly optimistic belief in realism. Hatvani used Einstein's pioneering Bebuquin as an illustrative case of literary-philosophical Grenzziehung:

In Worten, die sehnsüchtig vom Überfluß der Sprache nichts zu wissen scheinen, in Sätzen, die am Sinne bersten. So hat die Sprache nichts zu sagen und alles endet vor ihr. Bebuquin stottert nicht; aber die Philosophie seiner prosa ringt nach Atem. [. . .] Wesentlich ist nur die Verwesung; Verwesung ist Übergang zu höherem Wesen. Gedanken sind kokett in Unvergänglichkeiten verstrickt, würgen an den Tatsachen und errichten dem Leben das Denkmal der Abstraktion. [.. .] Es bleibt, als unerhörter Gewinn des Geistes, die Abstraktion. Prosa sei Abstraktion. [. . .] Prosa sei Revolution; Prosa ist Revolution. ("Prosaisches Weltbild" 35)

Thanks to abstraction, it is not the language that speaks but the artist. Hence, abstraction allows one to transcend the confines of conventional language. Abstraction becomes a way of abstaining from the objectification of experiential phenomena. On the one hand, by virtue of this evasion, Hatvani avoids the problems of nominalism in conventional language. On the other, prose composed in poetic language becomes synonymic with abstraction in his language philosophy.

Hatvani's Sprachkritik inevitably leads to the emergence of a "new epistemology" and, ultimately, a religious experience. The form of poetics that follows from his criticism of language promotes an alternative to the conventional subject-object scheme (the observing rational consciousness and what it observes). He called this alternative "latent mysticism." In a manuscript titled "Fehlrationalisierung der Weltgeschichte," Hatvani states that "wir mitten in einer Epoche symbolisticher Reaktion leben: die latente Mystik tritt mit exakten Systemen vor uns hin; neue Gruppierungen der Begriffe veraendern unsere Anschauungen" (2). Even though the manuscript was written rather late, Hatvani merely rephrased his earlier views concerning Sprachkritik that obstructed the mediation of the prevailing structures of power in language. ${ }^{16}$

For Hatvani, the new epistemology was inextricably linked with the novel aesthetics of the avant-garde, which rebelled against reactionary ideologies such as nationalism and antiSemitism. Indeed, revising epistemology was one of expressionism's prerequisites. In his 1917 essay "Versuch über Expressionismus," Hatvani stated that "Im Expressionismus überflutet das Ich die Welt," whereby he established a link between the avant-garde and mysticism, which was intentional considering that he was already familiar with the Kabbalah at this point (178). Hatvani's formulation unearths an interesting parallel between mysticism and the avant-garde in the question of selfhood and identity. For both the expressionist and the mystic, there was no strict distinction between the subjective and objective aspects of experience. In Hatvani's case the "I" that overflowed the world could not be monadic in any conventional sense. Without the feminine, the world would be a mere abyssal nothing for the "I"- that is, utterly unattainable. 
Author's Accepted M anuscript. When citing this article, please refer to 'The Avant-Garde Sprachkritik of Paul Hatvani: M ysticism, Eroticism, and Heterodox Religious Experience', Journal of Austrian Studies, 50:3-4 (2017), pp. 57-78.

The novel experiential aspect of Hatvani's theory evokes the subject-object scheme in a new sense. ${ }^{17}$ The experience of the absence of any difference between the subjective and objective, between the "I" and the world, echoes various kinds of ecstatic religious experiences abundant in mysticisms, not only Jewish ones. Sources are scarce in this respect, because Hatvani never documented his relation to mysticism in detail. However, he occasionally promoted imagery that suggested an association with the language theory of the Kabbalah. In this context the language of Creation becomes topical due to its extralinguistic capabilities: this was the language that had engendered the world. The Kabbalah held that the world never became devoid of this creative language; rather, there remained a mutual cosmological correspondence between the two (Stahmer 191). Adherence to such a conception was reinforced by Hatvani when he described how "Worte fielen in die Welt/Und Welten in die Worte" ("Vorlesung Else Lasker-Schüler" 6). Such dynamic bidirectional movement was enabled by the reciprocity of language and the world.

Adopting this conception of divine language had a decisive impact on Hatvani's cosmology. In 1917 he began to frame a new concept intermittently with the feminine, a concept that is grammatically neuter. From then on, a component he termed das Elementare or das Element lay at the heart of his gendered mysticism ("Versuch über Expressionismus"). ${ }^{18}$ In order to find an equilibrium of the mystical, the religious, and the modern, Hatvani arguably replaced the traditional Jewish idea of the Godhead with "the Elementary." In Judaism, the Godhead is the unknowable aspect of God that is beyond God's emanations and actions (Scholem 15-17). Moreover, the kabbalistic conception of the Godhead maintains that it has masculine and feminine aspects (Tirosh-Samuelson 191-92). Accordingly, Hatvani sought to circumvent the dilemma of naming the divine by suggesting an alternative term, namely "das Göttliche (so wollen wir es nennen, weil der Name Gottes, des Unaussprechlichen, vermieden werden soll)" ("Karl Kraus und die totale Satire" 76-77). Therefore, the Godhead and the Elementary are both ontological components that are beyond the epistemological grasp of the individual subject.

In mysticism, the Godhead was the aim of the mystic's desire and visions by which the gender dimorphism would be overcome. Hatvani appropriated this view for his avant-garde aesthetics when he stated that "Expressionismus war vor Allem die Revolution für das Elementare. [...] Der Weg zum Elementaren ist die Abstraktion" ("Versuch über Expressionismus" 176). Obviously, expressionism aimed at a comprehensive linguistic revolution, which would initiate abstraction as a way to the Elementary (the Godhead). Or, expressed in other words, the Elementary "erscheint als Resultat einer vollkommenen Abstraktion, die über die Form hinausführt" (Haefs 467). In Haefs's interpretation, abstraction enabled the discarding of formal elements from poetics. The Elementary can therefore be regarded as a formless ground, a kind of "murmur" left over from the subject-object scheme. Yet, Hatvani's thinking suggests a more profound understanding of the Elementary where abstraction is regarded as a potential means of expressing the encounter with the Godhead.

Such a "rendezvous" was possible due to the erotic nature of the encounter, reiterating the 
Author's Accepted M anuscript. When citing this article, please refer to 'The Avant-Garde Sprachkritik of Paul Hatvani: M ysticism, Eroticism, and Heterodox Religious Experience', Journal of Austrian Studies, 50:3-4 (2017), pp. 57-78.

dynamic exchange between the masculine and feminine in the Kabbalah. Abstraction was a path to the feminine that would not relinquish to the artist any cognitive aspect of its hidden mode d'être, as Hatvani argued:

Das Element kennt kein Kompromiß; es besteht für sich, in sich, aus sich: es ist. Nur das Element ist durch bloßes Dasein wirkend: so erfüllt es sich in einer Idee der Weiblichkeit. Der Mann schafft—das Weib ist; der Mann beweist sich der Welt durch das Bewußtsein—das Weib wird von der Welt bewiesen. So erhält—das Element einen geistigen Reflex vom Weibe[.] [. . .] Der Mann ist differenziert; der Künstler eine höher Potenz davon; der Expressionist die vorläufig höchstdenkbarste. Das Weib ist das Element. Und im Anfang war das Element. ("Versuch über Expressionismus" 147)

Here Hatvani approaches mysticism as he evokes the gender dimorphism of the Kabbalah. The feminine "Elementary" is primordial, which suggests that it is structurally similar to the Godhead if not indeed identical. Moreover, the masculine artist is transformed in the process, which echoes the kabbalistic conception of only circumcised adult Jewish males being able to unite with the feminine aspect of God (Tirosh-Samuelson 192).

The sort of primordial monism Hatvani was contemplating can only be understood in the light of kabbalistic theosophy. Wolfson notes that in the Kabbalah the feminine in fact becomes an extension of the masculine. Therefore, the "task of the homo religiosus [mystic or artist] is to restore the feminine to the masculine, to unite the two in a bond that overcomes gender dimorphism by establishing the complete male who embodies masculine and feminine. Ontologically, there is only one gender in kabbalistic theosophy, for the female is part of the male" (Circle in the Square 85). The androgynous male would be reestablished at redemption when the gender differentiation is finally overcome. This view also clarifies Hatvani's idea of the monadic man, which is paradoxical in a philosophical but not a mystical sense. Indeed, he almost reiterates the basic tenets of the Kabbalah in this respect.

Hatvani explained the intricacies of the masculine-feminine process of amalgamation in a manner sensible only within the context of mysticism.

Jedes Erlebnis ist erotisch und wird am Weiblichen,- -ein formloser Ausdruck einer Ausdruckslosigkeit—, zum Problem des Schaffens. Und der erlebende Künstler ist umso männlicher, je mehr er seine Umgebung, seine Materie, den Raum seines Erlebens, das Dasein oder die Welt, als "Weib" empfindet. Größtes Erleben ist höchste Männlichkeit und darum ist Gott, als Former und Gestalter einer formlosen Weiblichkeit "Welt" der absolute Mann, das Genie. Die Welt ist das Weib Gottes und seine Liebe ist unser Leben. (Salto Mortale 42-43)

First, the "formless expression of the lack of expression" denotes abstraction, which is dubbed as "erotic" because it is derived from an experience that is fundamentally erotic in character. Second, it proceeds along the lines of kabbalistic visions of gender and the eventual fulfillment of the masculine. As the artist approaches the feminine, the more masculine he becomes-which is paradoxical only if it is regarded outside the proper kabbalistic context in 
Author's Accepted M anuscript. When citing this article, please refer to 'The Avant-Garde Sprachkritik of Paul Hatvani: M ysticism, Eroticism, and Heterodox Religious Experience', Journal of Austrian Studies, 50:3-4 (2017), pp. 57-78.

which the figure of the androgynous male anticipates redemption. Finally, the amalgamation of the feminine into the masculine will result in the highest form of experience: the artist may have a fundamental unifying experience in the process of creation. Here Hatvani's heterodox religious experience becomes all the more pronounced, as it enables such an amalgamation for the artist. Ultimately, it is the fulfillment of religious desire.

It is here that Hatvani's idiosyncratic view on monads becomes understandable. It is less paradoxical when the monad is associated with infinity-Hatvani regarded infinity as being simultaneously open and closed: "Sie, die sie Gott nicht kennen, verleugnen auch das Mysterium der Schöpfung; denn mit der Schöpfung hat Gott die Quelle einer Kraft in die Welt gesetzt, die das Ich zum geschlecht, die Monade zur Unendlichkeit, den Mann zum Weibe führt. Und den Künstler zur Welt" (Salto Mortale 19). Here Hatvani highlights the hiddenness of God and the mystery of Creation by which God has placed a power into the world. As the Creation was verbal, Hatvani's argument can be understood as the assertion of language in the world; in other words, there remains a link between the world and language outside conventional language, reachable only via the language of the poet. Furthermore, Hatvani describes how man assimilates the feminine - that which represents the bodily, material world-into itself, thus completing himself and his world. The man hereby transforms from a monadic "I" into an infinity uncontained by monadic constraints. All this is to say that the Elementary represents a union of what is manifested as gender dimorphism in the world.

In "Spracherotik," Hatvani basically described a mystical experience with messianic overtones of a future deliverance. Such formulations were not uncommon in expressionism, especially in the works of authors like Ernst Toller, Paul Adler, Jakob van Hoddis, and Yvan Goll. ${ }^{19}$ Yet, regardless of their respective appropriations of kabbalistic themes, symbols, and imagery, none of them grounded the artist's experience in gender dimorphism<? $>$ the way Hatvani did. For him, man in the world was incomplete without the encounter-enabling imitatio Dei of the artist who had the privilege of experiencing divinity. As Hatvani states in the opening pages of Salto Mortale, "Von Wort zu Wort erbau ich eine Welt," thus moving the sprachkritische language center stage in the progressive dissolution of the "I" (7). This is not merely the subjective world of the poet but the cosmological world echoing Creation.

\section{Coda}

Hatvani's Sprachkritik distinguishes scientific and philosophical knowledge from poetical and mystical "knowing." Accordingly, a recurring theme in his fragmented literary production is the search for an unmediated mode of expression. While Sprachkritik provided the basis for a critical attitude toward language and rationality, Hatvani soon realized the importance and topicality of abstraction as both a means of literary expression and a mode of thinking that would not exert the subject's cognitive power over the objects of thought. The modern framework provided by the avant-garde supported his appropriation of Jewish mysticism. For instance, the Elementary 
Author's Accepted M anuscript. When citing this article, please refer to 'The Avant-Garde Sprachkritik of Paul Hatvani: M ysticism, Eroticism, and Heterodox Religious Experience', Journal of Austrian Studies, 50:3-4 (2017), pp. 57-78.

assumed the place of the Godhead while veiling God beyond all experiential and cognitive speculations. The Elementary, for one, is manifested as the hypostatized feminine in the world of the artist. This is to say that due to an internal lack, the subject can never be complete without the feminine. Ultimately, the artist may arrive at a union with the feminine on an experiential level and thus transform, but the Elementary seems nonetheless absent from this world and, hence, the grasp of language. The sole way to "come into contact" with the Elementary was provided by abstraction - that is, approximation.

The foregrounding of modern and vanguard ideas concerning religion render Hatvani a heterodox thinker. Heterodox religious desire, exemplified by the feminine, can only be associated with Judaism by means of an extension of the latter, which—-together with Hatvani's idea of an "evolving" Judaism - gives rise to the limits of that religion; in other words, to what extent are Hatvani's Kabbalah-influenced theories actually Jewish? These issues need to be investigated further in relation to the broader field of Jewish participation in the avant-garde. By the same token, Hatvani's position in Austrian letters requires a new assessment as the relations between Jews and the various avant-garde movements undergo reevaluation.

Sami Sjöberg is an Academy of Finland Research Fellow at the University of Helsinki, holding a Ph.D. in comparative literature. His most recent and forthcoming publications include "An Other Transnationalism: Romanian Jewish Emigrants in Francophone Avant-Gardes from the 1920s to the 1950s" (Forthcoming in French Studies), "Isou et la question juive : sur l'idée de continuum" (Les Presses du réel, 2018), "Literaturrevolution in Continental Jewish Aesthetics" (arcadia, 2016), and a volume of essays co-edited with Mark H. Gelber, titled Jewish Aspects in AvantGarde: Between Rebellion and Revelation (De Gruyter, 2017). Sjöberg has also translated French experimental literature (e.g. Alfred Jarry, Georges Perec) and published widely on Continental avant-garde literature and its relation to Judaism as well as contemporary European art and the poetics of the avant-garde.

\section{Notes}

1. Sprachkritik studies language, speech acts, and discourse, focusing on the relationship between language and cognition, particularly with the aim of illustrating the impossibility of such a relation. Its earliest proponents in the German-speaking world were Fritz Mauthner, Hugo von Hofmannsthal, and to some extent the early writings of Gustav Landauer. Strictly speaking, the language philosophy of Ludwig Wittgenstein does not adhere to Mauthnerian principles. Mauthner and Hofmannsthal focused on words, unlike Wittgenstein. The Wittgensteinian approach, focusing on sentences, maintained that descriptive sentences were facts themselves whereas Mauthner's language crisis encompassed scientific, descriptive language.

2. Hatvani's unpublished material is currently located in the Rare Book Collection, Monash University Library, Melbourne.

3. Haef's essay is the most detailed historical account of Hatvani's literary career to date, together with Hesse.

4. For a broader account of the history of the phenomenon, see Kiesel 177-232; Konitzer.

5. Hatvani appears to have been familiar with Gustav Landauer's 1901 article "Mauthners Sprachkritik," based on certain formulations of his own in "Spracherotik."

6. For a further discussion on Kraus's Sprachkritik, see his Sprüche und Widersprüche (1909). Hatvani was 
cognizant of Kraus's and Mauthner's theories when he wrote Salto Mortale. In a manuscript entitled "Gott und die 'Fackel'" (likely 1974), Hatvani uses the term Sprachkritik and its derivatives numerous times. The manuscript was an early version of his "Karl Kraus und die totale Satire" (1975), which, however, omits the term.

7. Mauthner and Kraus realized that poetry could circumvent the conventional system of reference applied in everyday language. They regarded poetry first and foremost as a form of individual expression, and its relation to the world was a secondary concern as far as any referential accuracy was concerned. Hatvani, however, went beyond the "practical" grasp of Sprachkritik by formulating that art—which enabled an alternative relation to the world-was "zu Gott gesteigerte Menschlichkeit" (Hatvani, "Volkskunst" 196). Art could only be "attained" through a personal reflection on the character of language, which is reminiscent of the contemplation of the very same medium in Jewish mysticism. Significantly, like Mauthner before him, Hatvani referred explicitly to mysticism in a sprachkritische context.

8. Both variants adopted the idea of Adam Kadmon, the "original man," who was androgynous. In the Zoharian Kabbalah Adam Kadmon is the result of a divine emanation, whereas in the Lurianic variant the original man mediates between God and the emanations (Schwarz 15-16).

9. One should also note that the feminine (weiblich) refers to grammatical gender in German, which is important as it highlights Hatvani's theories' relevance to language.

10. Such gendered aspects undermined any strictly defined Jewish monotheism and were thus radically antinomian in the Jewish sphere.

11. Hatvani also acknowledged how the particularity of the Jews as a community fundamentally differed from those of Catholics and Protestants in Germany at the time (Hatvani, "Bemerkungen über Irreligisiotät").

12. In addition to the myth of Creation, the term creative most likely derives from Salomo Friedlaender's seminal work Schöpferische Indifferenz (1918), which, in the wake of Max Stirner, influenced numerous avant-gardists and philosophers, such as Tristan Tzara and Walter Benjamin.

13. For more on this, see Mehtonen; Sjöberg, "Mysticism of Immanence."

14. Hatvani most likely chose not to employ the more frequently used term Wortkunst due to the broader scope of Sprachkunst that accounts for the philosophical aspect of Sprachkritik.

15. Furthermore, Hatvani connected abstraction (as a mode of thought) with the idea of a new Jewish consciousness that he had outlined. Hence, in an idiosyncratic manner, he seems to parallel the avant-garde esthetics with the ethnic-religious frame of his theory.

16. This is to say that once conventional language was subjected to Sprachkritik, it would not lend itself to any mediation of ideologies. For instance, the nominalist would not read much into the term Heimat, which was very meaning-laden in German-speaking Europe of the 1930s.

17. In terms of this aspect, Hatvani's and Mauthner's theories greatly resemble each other. The latter anticipated Hatvani's claim concerning a new epistemology, yet opted for a more philosophical formulation. According to Mauthner, "Was ich erleben kann, das ist wirklich. Und ich kann es erleben, für kurze Stunden, daß ich nichts mehr weiß vom principium individuationis, daß der Unterschied aufhört zwischen der Welt und mir" (Mauthner, Wörterbuch der Philosophie 284).

18. Within this framework, Hatvani clarified the artist's (and mystic's) favorable position over the scientific one. According to him, "Falsch aber ist es, die Tendenz des [Künstlers] mit der wissenschaftlichen Dialektik religiöser oder antireligiöser Richtung gleichzusetzen; wir müssen hingegen betonen, dass Gott und der Glaube stetz ausserhalb der sprachanalytischen und daher auch moralischen Betrachtungen" (Hatvani, "Gott und 'Die Fackel'" 34). Therefore both God and faith are beyond the language-analytical sphere and, furthermore, beyond the heterodox desire of the artist as well.

19. Cf. Sjöberg, "Redemption, Utopia, and the Avant-Garde" and "Remaking the Present through Language." 
Author's Accepted M anuscript. When citing this article, please refer to 'The Avant-Garde Sprachkritik of Paul Hatvani: M ysticism, Eroticism, and Heterodox Religious Experience', Journal of Austrian Studies, 50:3-4 (2017), pp. 57-78.

\section{Works Cited}

The estate of Paul Hatvani, Rare Books Collection, Monash University Library, Australia. Dates in square brackets indicate approximation.

Bojtár, Endre. "The Avant-Garde in East-Central European Literature." History of the Literary Cultures of East-Central Europe: Junctures and Disjunctures in the 19th and 20th Centuries, editing by Marcel Cornis-Pope and John Neubauer, pp. 364-75, John Benjamins, 1984.

Friedlaender, Salomo. Schöpferische Indifferenz. Georg Müller, 1918.

Goff, Philip. Spinoza on Monism. Palgrave Macmillan, 2011.

Haefs, Wilhelm. "'Der Expressionismus ist tot ... Es lebe der Expressionismus': Paul Hatvani als Literaturkritiker und Literaturtheoretiker des Expressionismus." Expressionismus in Österreich. Die Literatur und die Künste, edited by Klaus Amann and Armin Wallas, 453-85, Böhlau, 1994.

Hatvani, Paul. "Bemerkungen über Irreligisiotät." MSN C2, 1918. Unpublished.

. "Bemerkungen zum Zeitalter und Stil des Expressionismus in der deutschen Literatur." MSN D4-2, s.a.

. "Der Expressionismus ist tot ..." Renaissance, vol. 1, 1921, pp. 3-4.

. "Fehlrationalisierung der Weltgeschichte." MSN C4, [1934]. Unpublished.

. "Gott und 'Die Fackel."' MSN D4-I6-2, [1974]. Unpublished.

. "Jüdische Besinnung." Der Jude: eine Monatsschrift, vol. 2, 1917-1918, pp. 718-719.

. "Karl Kraus und die totale Satire." Modern Austrian Literature, vol. 8, 1975, pp. 61102.

. "Prosaisches Weltbild." Die neue Schaubühne, vol. 2, 1920, 33-35.

. "Spracherotik." Der Sturm, vol. 3, 1912, p. 210.

-. Salto Mortale: Aphorismen, Essais, Skizzen. Saturnverlag Hermann Meister, 1913.

. "Versuch über Expressionismus." Die Aktion, vol. 7, 1917, pp. 146-50.

. "Volkskunst." Der Sturm, vol. 4, 1914, pp. 196-97.

. "Vorlesung Else Lasker-Schüler." Der Sturm, vol. 3, 1912-1913, p. 6.

Hesse, Silke. "Nachwort." Paul Hatvani: Die Ameisen, Universität-Gesamthochschule, 1994.

Kiesel, Helmut. Geschichte der literarischen Moderne: Sprache, Ästhetik, Dichtung im zwanzigsten Jahrhundert. C. H. Beck, 2004.

Konitzer, Werner. Sprachkrise und Verbildlichung. Könighausen \& Neumann, 1995.

Kraus, Karl. Sprüche und Widersprüche. Albert Langen, 1909.

. Über die Sprache. Suhrkamp, 1985.

Landauer, Gustav. "Mauthners Sprachkritik." Die Zukunft, vol. 35, 1901, pp. 220-24.

Mauthner, Fritz. Beiträge zu einer Kritik der Sprache. Volume 1. J. G. Gottasche, 1901. Wörterbuch der Philosophie. Felix Meiner, 1923. Print.

Mehtonen, Päivi. "Nominalistic Mysticism, Philosophy and Literature." Ambiguity of the Sacred: Phenomenology, Politics, Aesthetics, edited by Johanna Bornemark and Hans Ruin, pp. 
Author's Accepted M anuscript. When citing this article, please refer to 'The Avant-Garde Sprachkritik of Paul Hatvani: M ysticism, Eroticism, and Heterodox Religious Experience', Journal of Austrian Studies, 50:3-4 (2017), pp. 57-78.

131-46, Södertörn, 2012.

Scholem, Gershom. The Mystical Shape of the Godhead: Basic Concepts in the Kabbalah. Trans. Joachim Neugroschel. Schocken Books, 2011.

Schwarz, Howard. Tree of Souls: The Mythology of Judaism. Oxford University Press, 2004.

Sjöberg, Sami. "Mysticism of Immanence: Lettrism, Sprachkritik, and the Immediate Message." Partial Answers, vol. 11, 2013, pp. 53-70.

. "Redemption, Utopia, and the Avant-Garde: German-Jewish Visions of the Future." Utopia, edited by David Ayers et al., pp. 185-98, De Gruyter, 2015.

. "Remaking the Present through Language: Messianic Time in the Works of Yvan Goll and Isidore Isou contra Benjamin and Agamben." Journal of Modern Jewish Studies, vol. 14, 2015b, pp. 199-214.

Stahmer, Harold. "Speak That I May See Thee!": The Religious Significance of Language. Macmillan, 1968.

Tirosh-Samuelson, Hava. "Gender in Jewish Mysticism." Jewish Mysticism and Kabbalah: New Insights and Scholarship, edited by Frederik E. Greenspahn, New York UP, 2011.

Wallach, Kerry. "Paths of Modernity: Jewish Women in Central Europe." The Wiley-Blackwell History of Jews and Judaism, edited by Alan T. Levenson, pp. 422-39, John Wiley, 2012.

Wolfson, Elliot R. Circle in the Square: Studies in the Use of Gender in Kabbalistic Symbolism. SUNY Press, 1995.

. "Occultation of the Feminine and the Body of Secrecy in Medieval Kabbalah." Rending the Veil: Concealment and Revelation of Secrets in the History of Religion, edited by E. R. Wolfson, pp. 35-68, Seven Bridges Press, 1999.

. "Imagining the Imageless: Iconic Representations of the Divine in Kabbalah." Iconotropism: Turning towards Pictures, edited by Ellen Spolsky, pp. 57-68, Bucknell UP, 2004. 